\title{
Placemaking and visitors' reviews of the Golden Mile of Durban
}

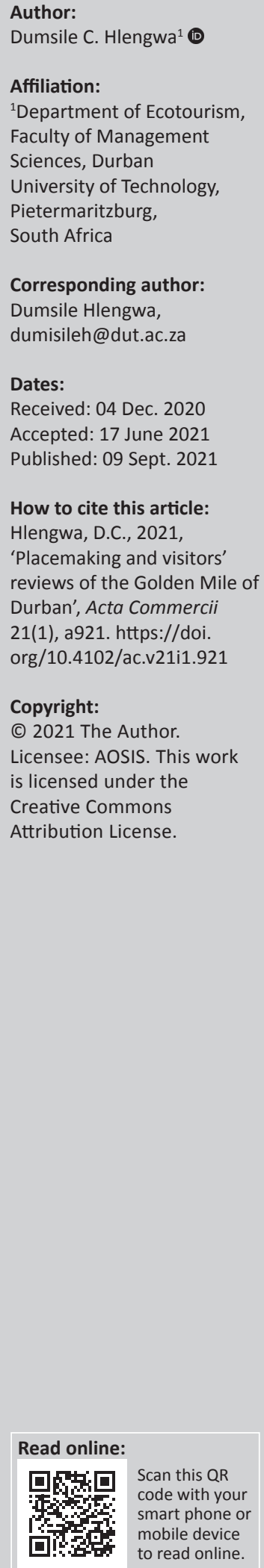

Orientation: Placemaking is a proclivity of cities to change space into place through zoning, naming and development into attractive, people-friendly landscapes where diverse, harmonious and sometimes contradicting amenities are coalesced to attract people.

Research purpose: To establish the perceptions of the visitors on appeal, experience and safety of the Golden Mile of Durban.

Motivation for the study: The study was motivated by availability of online reviews that remained unanalysed and did not aid decision-making.

Research design, approach and method: Data were collected from 287 reviews sampled from the Golden Mile website. Qualitative analysis was performed on the data and categorised according to appeal, experience and safety associated with the Golden Mile.

Main findings: The study found that placemaking is always work in progress as destinations strive for competitiveness and to avoid obsoletion. An overwhelming majority of visitors rated the Golden Mile as good to excellent on appeal, experience and safety. Some criticised the place as unsafe with a number of dilapidated buildings spoiling its appeal.

Practical/managerial implications: Planners and tourism developers should factor the grass root approach to placemaking by increasing security and urging property owners to revamp their buildings, thus keeping with the image of the place.

Contribution/value-add: The article emphasises the significance and value added by online visitors' reviews in placemaking.

Keywords: Golden Mile; placemaking; visitors' reviews; appeal; experience; safety.

\section{Introduction}

The Golden Mile (Mile) of Durban in the province of KwaZulu-Natal is considered as one of South Africa's most iconic public places (Cloete \& Yusuf 2018) serving locals' and visitors' needs for open spaces (Open Streets 2017). The development and upgrades currently underway are a deliberate and planned activity to make the Mile attractive (Kolas 2004) and 'take Durban to the world', (Matema 2018:1) by turning it into a place where 'South Africa, if not the world, will rendezvous' (Durban Point Waterfront 2020). This development will be made up of seven precincts including the completed promenade (recreation, residential, warehousing, harbour entrance, pedestrian access points and transport node) that will be thrown together to make the place as competitive as Copacabana in Rio, Bondi Beach and Surfers Paradise on the Gold Coast of Australia (De Villiers 2019; Durban Point Waterfront 2020; Naidoo 2019:1). Whilst the Durban Point Waterfront (2020) Master Plan does mention developers, stakeholders and investors, it was silent about the role to be played by users in the development and how their voices were factored in. De Brito and Richards (2017) and Elrahman and Asaad (2020) question the relevance of top-down placemaking approaches that do not consider the input of users. Elrahman and Asaad (2020) and Wesener et al. (2020) argued in favour of multidisciplinary, participatory and grass roots design approaches to placemaking that consider the human dimensions of a place and inspire users to collectively (De Brito \& Richards 2017:3) 'reimagine and reinvent' their public places as heartbeats of the community and its visitors. Toolis (2017) and Wesener et al. (2020) regarded collective approaches as critical to placemaking as they allow users to reclaim public places through their voices. 
It is important to consider and factor in the reviews of the users when planning future developments. As Kitingan (2019) argued, online reviews are a good way to identify areas of improvement because they are voluntarily written by real people, thus (Schuckert, Liu \& Law 2015) providing free powerful information. This accords visitors a dual role of being users and (Kim et al. 2019) active information generators about the place for both future users and developers, as opposed to a (Barrera-Fernández \& Hernández-Escampa 2017) tourism model in which the users are passive and voiceless consumers.

Although online reviews and uploaded images have become increasingly important because they are up-to-date, readily available and serve as word-of-mouth recommendations and critiques allowing potential visitors to make informed decisions (Cerutti \& Piva 2016; Dediu 2016; Schuckert et al. 2015), they are of limited use if not consolidated to inform future developments. In a study conducted in Amsterdam, Breek et al. (2018:9) found that people describe online social media as platforms to get things that need attention to 'come together' and 'get out there'. It is assumed that is what eThekwini Municipality (custodian of the Mile) was aiming for when creating the review page for the Mile.

This article used visitors' reviews, available on the website to determine their perceptions of the appeal, quality of experience and safety, which emerged as three of four important attributes in the reviews of the Mile as a place to visit. The aim was to attempt to bring together scattered data to aid decisionmaking as the Mile is being upgraded for global relaunch. Whilst social media platforms are seen as catalystic for social interaction and vibrant platforms to steer bottom-up contribution to placemaking (Brynskov et al. 2014), little is known about how they function to influence placemaking (Breek et al. 2018). The literature on placemaking provided the expectations and context against which visitors' online reviews of the Mile were to be understood and analysed.

The Golden Mile of Durban (Figure 1) stretches approximately $8 \mathrm{~km}$ from the Blue Lagoon, Umngeni River mouth to the end of the sea-front promenade marked by the north pier. The Mile may be considered to subscribe to the concept of thrown togetherness as advocated by Cloete and Yusuf (2018), Jagganath (2018) and Massey (2005) as the place is made of an assortment of facilities and activities that shape its image as a destination. It includes natural features, various recreation, sporting and conferencing amenities. The Mile gives access to sea and beaches, the blue lagoon, the Green Hub, a mini town, stadia, the Suncoast Casino, the International Convention Centre, the Exhibition Centre, uShaka Marine World, the sea-front promenade, swimming pools, gardens, hotels, restaurants, fast food shisanyamas and a web of roads for access and parking. The sea-front promenade extention (the longest uninterrupted waterfront promenade in Africa) opened in November 2019 and is expected to spur further investment, making the Mile (Durban Point Waterfront 2020) 'the city's most important tourism asset'.

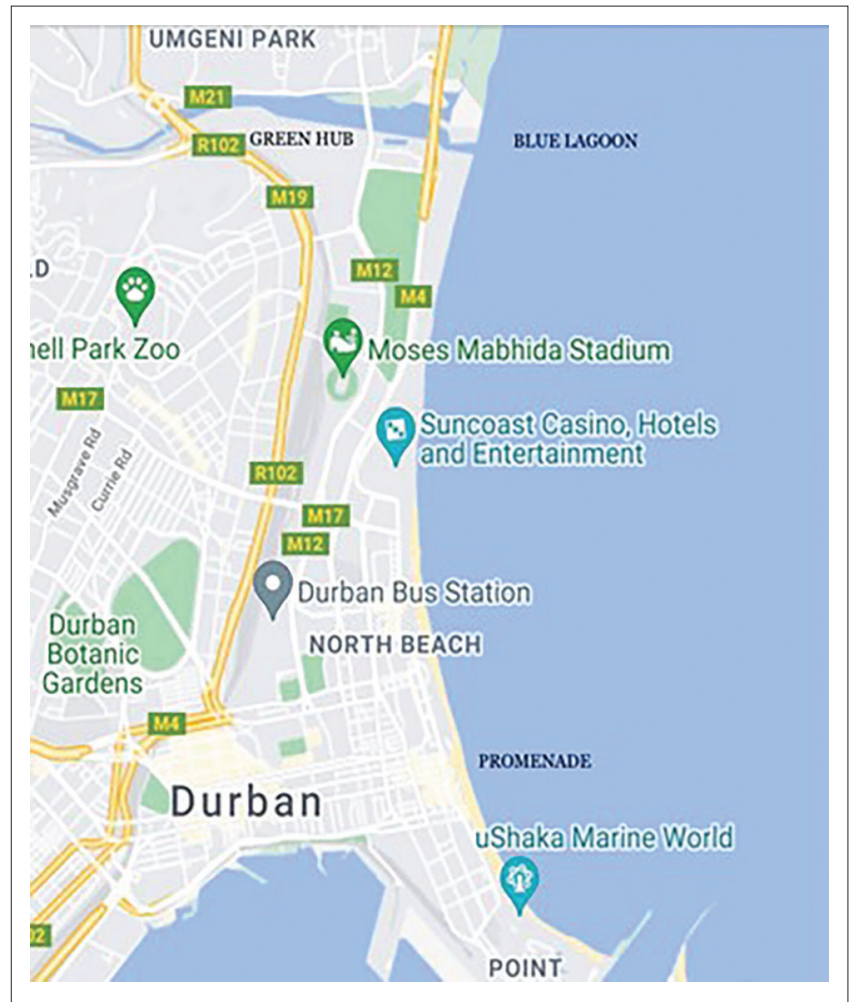

Source: Geographic Information System (GIS), 2021, viewed 12 July 2020, from https://www. google.com/maps/search/GIS+2021+map+of+kwazulu+natal/@-28.9262832, $28.6383794,7 \mathrm{z} /$ data $=$ !3m1!4b1

FIGURE 1: Map of the Golden Mile.

\section{Literature review}

Tourist destinations are designed to lure visitors (Baldacchino 2012; Rocamora 2019) through their popularity, freshness (Alrawadieh et al. 2018) and ability to help visitors realise their expectations (D'Orey, Cardoso \& Abreu 2019). Visitors expect a coexisting multiplicity (Baldacchino 2012; BarreraFernández \& Hernández-Escampa 2017) of features such as culture, architecture, infrastructure, landscape, events, shopping, gastronomy, transportation, sporting facilities, nightlife, events and social performances to enhance the image and feel and position the place as a destination of choice (Vinyals-Mirabent 2019). The local municipality and tourism developers have to throw these features together in a complementary, yet disruptive way to flaunt the genuine uniqueness of the place (Alim, Ray \& Hossain 2018), giving visitors impetus to choose it (Ferreira \& Perks 2018).

Space is something absolute, physical, a 'thing itself' (Chatzidakis, McEachern \& Warnaby 2018:150), which stands in view and not related to experience. Space is neither predetermined nor fixed, it merely defines location. A place on the other hand, is a feature of architectural design within the context and confines of environmental elements (Ghoomi et al. 2015; Raissi \& Eshghi 2012) that twine with human experience to make it a social reality. The identity of any place forms through a combination of factors including the physical environment, cultural landscape, behaviour of people and the value that visitors gain from and give to it (Blaschke et al. 2018; Parsaee, Parva \& Karimi 2015). Place is cultured and characterised by subjective interpretations and 
human activities, which cultivate a sense of place (Chatzidakis et al. 2018). Critical attributes include such an agglomeration as physiography, climate, geographic location, natural, cultural and heritage resources, man-made structures, events, ease of movement, uniqueness, cleanliness and perception of safety together sell fantasies, feed visitor expectations (Atinafu \& Muuz 2017; Hossain \& Islam 2019; Martins 2015; Vinyals-Mirabent 2019) and develop the character and spirit of a place (Harvie 2020) to enrich visitors' experiences. Kim et al. (2019) aligned these attributes with feelings of escapism, relaxation and self-esteem, thus highlighting the importance of determining attributes that help the destination live up to visitor expectations by throwing together and managing (Dwyer et al. 2004) an amalgam of place products and experience opportunities.

In their study conducted in Sabah, Malaysia, Wong and Kaur Kler (1977) argued that space is empty and abstract, but human intervention, experiences, relationships, emotions and thoughts turn spaces into places by breathing life into them, thus transforming them into places with meanings. Places get made, unmade and remade as templates of creativity (Baldacchino 2012; Friedman 2010; Gagnon, Jacobs \& McCabe 2014) through (Fleischer et al. 2013:5228) disordering and then reordering to improve appeal, connectivity and sense of place (Rocamora 2019). As the place evolves it becomes a blend of geographical, physical, sociological and psychological features (Roult, Adjizian \& Auger 2016) of socio-spatial experience from the inside (Chatzidakis et al. 2018). A place then becomes a totality of physical and cultural features, its people, synergies and contrasts it presents, its ambiance and experiences it offers (Ghoomi et al. 2015:276) allowing people to form flexible settings to order and experience as they choose (Baldacchino 2012; Fleischer et al. 2013; Massey, Allen \& Sarre 1999).

Placemaking as a concept was developed by urban designers Jane Jacobs and William Whyte back in the 1960s. Academic interest in placemaking surged in the 1990s, across many disciplines such as architecture, urban design, landscaping, geography, social sciences, tourism and others as urban sprawl displaced people with hard antisocial structures rendering cities unliveable and people placeless (Friedman 2010; Lew 2017; Zhao 2019). The concepts of placemaking and cultural ecosystems emerged to provide solutions to placelessness in cities (eds. Cheer \& Lew 2018) by making better places for people with different identities to live, work, visit, explore, enjoy and invest through juxtaposing contradictions of culture and innovation (De Brito \& Richards 2017; Ghoomi et al. 2015) in place-specific ways.

Tourism planning, development and management are placemaking actions that shape places and enhance their image as a destinations (Elrahman \& Asaad 2020; Lew 2017; Sofield, Guia \& Specht 2017) of multiple socio-spatial experiences (Friedman 2010; Harvie 2020; Mottier \& Ryan 2019; Northrop \& Neumann 2016; Sofield et al. 2017). In the field of tourism, placemaking is operationalised because tourism-related planning and marketing concern themselves with consumption of natural and built environments, landscape, image, appeal, diversity, coexistence of contradictions, experience, fantasy and safety (Lew 2017; Zhao 2019) which cities have to loosely and skilfully interlace. In studies conducted in Wuxi, China and Luang Prabang, Laos and Zhao (2019:599) and Staiff and Bushell (2017), respectively, observed that placemaking is an ongoing dynamic process of construction and re-construction where the mixture of ancient and modern, traditional and the contemporary are continuously re-constituted to cater for visitors with different tastes and styles, because in tourism, development is 'other-directed', packaged and commodified using consumer-oriented designs (Cloete \& Yusuf 2018). To this end planners and developers layer structures and meanings to form a harmonious coexistence of opposites, such as order and disorder, simple and complex, private and public, innovative and traditional, natural and man-made to appeal to diverse users. A place is also viewed as a distinctive and particular entity, a setting for social interactions (Chatzidakis et al. 2018; Roult et al. 2016) and a kaleidoscope of elements, designs, landscaping, objects, colours, shapes, sounds, movements, people, etc. inseparably linked through a symbiotic interaction with visitors (Zhao 2019), thus giving it a spirit and personality. This symbiosis of variety accords a place an irreplaceable niche in the socio-spatial fabric of destinations, making it likely or unlikely to be visited again.

\section{Significance and value of a place}

Visitors' experience of a place can have symbolic value of intangible and multilayered meanings and functional value of affective and social significance (Ram, Bjork \& Weidenfeld 2016; Ramkinssoon, Weiler \& Smith 2012; Tsai 2012; Yuksel, Yuksel \& Bilim 2010). The sense of place is a holistic dimension explaining the relationship between an individual and a place influenced by visual experiences linked to viewsheds symbiotically thrown together and interlaced at the attraction (Barendse et al. 2016; D'Orey et al. 2019) branding it apart from other places. Blaschke et al. (2018) argued that placemaking requires place-based geographic information system (GIS) representativity of features to enhance access, communication, comfort, liveability and safety across generational divide. Sense of place is a (Zhao 2019:598) 'stream of awareness composed of place images, place significances and place engagements' produced through interactions between visitors and locals to develop place consciousness, significance and emotional attachment making it the most sought-after destination (Abou-Shouk et al. 2017; D'Orey et al. 2019).

In tourism a place is a destination that individuals enjoy and connect with because it helps them to realise their expectations (D'Orey et al. 2019). Contextual information, attitudes and other images collaboratively play significant roles in creating these connections and meaning (Williams 2014) as experiences align with expectations (D'Orey et al. 2019). Sense of place relates to the effect of place on the profile of the visitor (Smith 2019), resulting in different profiles of visitors experiencing the same place differently because of their background, 
culture and level of cognitive development (Blaschke et al. 2018; Ebejer 2014). Being in the place may evoke feelings of openness and endlessness (Massey et al. 1999) that align with expectations and enhance experience. Therefore, a destination's competitiveness should be niche-specific (Neto et al. 2019) and dependent on the ability to brand itself to occupy a desired position in the long term (Vinyals-Mirabent 2019), by meaningfully throwing together in a unique way, an array of features. Destination attractiveness, competitiveness and resilience depend on the development and enhancement of place attributes viewed as critical by different visitors (Abel \& Le Roux 2017; Calderwood \& Soshkin 2019; Haarhoff \& Gany 2017; Hossain \& Islam 2019; Neto et al. 2019). Dwyer et al. (2004) and Rodríguez-Díaz and Pulido-Fernández (2019) perceived destination competitiveness as relating to the overall experience visitors judge as superior to those of alternative destinations.

Zhao (2019) posited that when visitors give meaning to the array of features and develop feelings of being in a place, they are transforming such features into features and feelings of their own world and developing an intimate relationship with the place. This happens when the spirit of the place and that of the visitor embrace leading to fantasies as the place becomes the 'home of hearts' full of feelings and emotions (Trauer \& Ryan 2005:482) that only the visitor understands. A tourism destination is a place of escape that may possess elements of recreation, recovery and self-love. To some visitors destinations become centres of meanings, activity, experiences and attachment (Ebejer 2014; Friedman 2010; Wagenaar 2011), whose significance is derived from the conscious engagement with the feelings evoked by being there (Ebejer 2014). A place derives meaning from the local or regional content and context (Trancik 1986), therefore, its design and structure should reflect human presence (Dameria, Akbar \& Indradjati 2018; Tuan 1977) through an array of features, activities and conceptions (Dameria et al. 2018; Relph 1993).

\section{Value of online reviews}

From their experiences of a place, visitors generate and upload information to online sites, which can help destinations understand visitor expectations and their image of the destination (Bruno et al. 2019; Dediu 2016; Ye \& Tussyadiah 2011). Online reviews empower potential visitors as they clarify information about a place, thus dealing with unrealistic expectations (Ye \& Tussyadiah 2011). Online reviews are 'user-created content' that help potential visitors to plan their journeys with respect to attractions, activities and experiences to expect at destinations (Dediu 2016:2). In agreement, Breek et al. (2018:1) pointed out that social media 'engender an active process of giving meaning' to places. About $90 \%$ of tourists are reported to read online reviews on a destination before making any travel choice, and about $75 \%$ of them rate online reviews as important and powerful factors in travel decision-making (Cerutti \& Piva 2016; Fox 2019; Hlee, Lee \& Koo 2018). Online reviews are considered by readers as credible, giving power to consumers as co-creators of places through their own feedback and suggestions (Hlee et al. 2018), which is the reason many potential travellers spend time reading online reviews to assist in travel decision-making (Schuckert et al. 2015).

\section{Methodology}

The researcher collected visitors' reviews available on the website of the Mile of Durban. The pages available on the website spanned a period of 10 years from 2010 to 2019 and there was a total of 161 pages. The researcher used a table of random numbers to select 58 pages used for this article. Numbers were selected randomly from the top of column to the bottom until all 58 pages were selected. Numbers beyond 161 were skipped as this was the maximum number of pages of reviews. There were 891 reviews available on the 24th December 2019. Each page contained reviews from various parts of the country and the world, in cases where places of residence were given.

This article was based on reviews ranging from 2014 to 2019. Such data were used to determine the perceptions of visitors of the Mile as a place and a destination. The aim was to coordinate and give meaning through readily available visitor feedback data for use in planning, decision-making and the underway remaking of the Mile. At five reviews per page, 290 reviews were selected and 287 were found to be usable. The three that were eliminated did not provide usable data such as their experiences of the Mile. The recording of data indicated that reviews tended to be based on the appeal, experience, safety and cleanliness as attributes, but the article focussed on appeal, experience and safety issues as these three were more prevalent attributes in the reviews. The developments underway along the Mile are aimed at enhancing its international appeal and competitiveness. Safety was considered important as the $2.1 \%$ decline in tourist arrival from January to September 2019 had been blamed on safety and security by the Minister of Tourism (Smith 2019:1), making these attributes stand out in the reviews.

The researcher also collected, where mentioned, the places of residence of the reviewers and the year of the review, which made data quite rich as reviewers came from countries around the globe. Dediu (2016) pointed out that online reviews are free and subjective qualitative texts, where people who have visited the place share their opinions, perceptions and feelings about the place. The design was exploratory starting with data collection and recording, sorting, categorising into derived themes, sorting according to stars awarded, which was then followed by analysis and interpretation. The analysis and interpretation followed qualitative approaches.

\section{Results}

Raymond, Gottwald, Kouppa and Kytta (2016) argued that place images and attachments are slow to evolve, with the implication that depending on their experiences of the 
place, they will hold the place in that regard for a long time. It is therefore important for destinations to strive to make good impressions on visitors first time. The overall reviews ranging from excellent (5-star), very good (4-star), average (3-star), poor (2-star) to terrible (1-star), can be understood against the assertion by Blaschke et al. (2018) and Ebejer (2014) that different profiles of visitors will experience the same place differently because of their background, culture and level of cognitive development. An overwhelming majority of $82.6 \%$ (237) rated the Golden Mile between excellent and very good, with $17.4 \%$ (50) rating it between average and terrible (Figure 2).

Figure 3 illustrates that there was a fairly good mixture of reviewers coming from various parts of the globe. Of the total of 287 reviews used for this article $33.8 \%$ (97) were local (from KwaZulu-Natal), 28.6\% (82) were international, 26.5\% (76) national, only $0.7 \%$ (2) from the rest of Africa and the remaining $10.5 \%$ (30) unknown because they did not disclose their home countries. For 5-star rating, there were 145 reviews from 2014 to 2019 , which formed $50.5 \%$ of the total sample. Of these 145 reviewers, 90 (62\%) were from different parts of South Africa, 35\% came from other parts of the world including America, Europe, India, United Arab Emirates, China, Australia and some parts of Africa and the remaining $3 \%$ did not include places of residence, as was the case with the study conducted by Kladou and Mavragani (2015) on Turkey and Istanbul using reviews from TripAdvisor ${ }^{\mathrm{TM}}$. Kladou and Mavragani argued that people have an option to omit their personal details especially because they are not the focus of attention.

\section{Reviews on appeal}

The majority of reviewers who gave the Mile 5-stars for appeal described the place as beautiful, must do, lovely, awesome, world class, stunning, excellent, perfect,

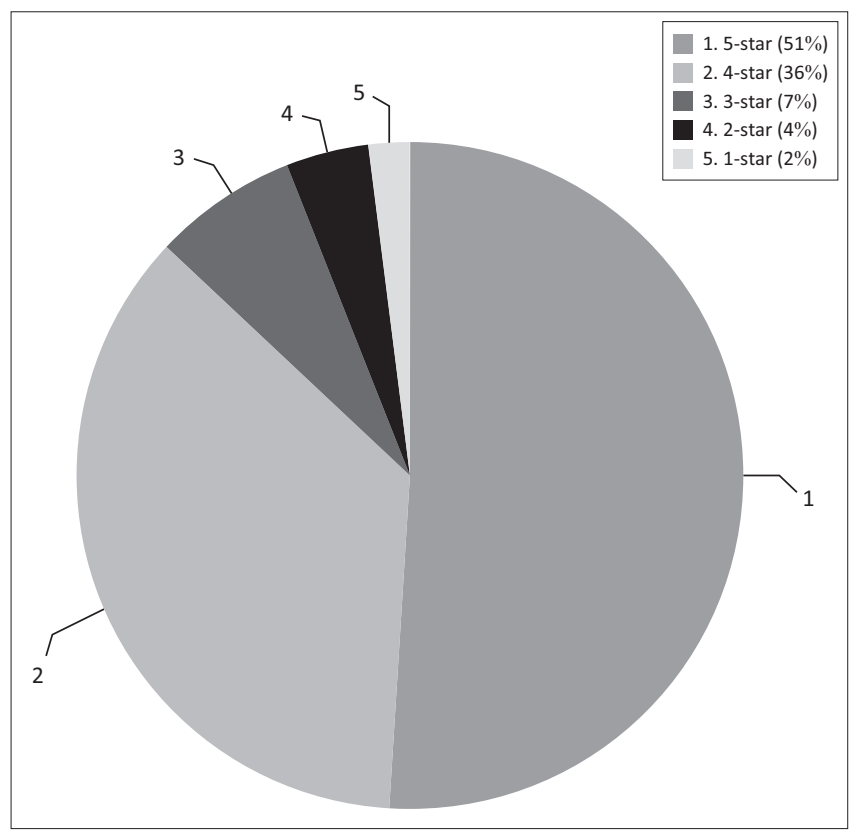

FIGURE 2: Overall impression of the reviewers. Star rating of the Mile by visitors. amazing, nice, vibrant, relaxing, wonderful, the best place with fantastic views. They also commented on variety, stating that the place offered a lot to see and do. There were some reviewers who felt the Mile was one of the things to do when in Durban because it was the heartbeat of the city that lucky Durbanites should be proud of. Reviewers regarded facilities such as the beaches, stadium, paved pathways and the promenade as impressive. The online reviews concur with Cloete and Yusuf (2018) when they describe the Mile as South Africa's most iconic public place.

Even though not the objective of this article, the reviews highlight some of the place attributes identified by Toral, Martínez-Torres \& Gonzalez-Rodriguez (2017), as important to visitors such as the physical (sea, weather, sun, views, flatness and gardens), architectural (stadia and pathways), variety (endless options, lots to do and multiuse). Just 105 $(36.6 \%)$ reviewers over a period of 5 years evaluated the Mile as a four star place. More than half $(61 \%)$ of those reviewers were from different parts of South Africa, 27\% were from various parts of the world as stated before and $12 \%$ did not disclose their areas of residence. The 4-star positive comments were similar to five star comments.

About a 10th of reviewers (31) reviewed the Mile as an average, 3-star attraction. Some of the reasons for 3-star grading were overcrowding, poor maintenance and rundown hotels and flats. Their comments as middle of the way were as important as 5 -star and 1-star comments. It is worth mentioning that most of the negative reviews (7) came from local visitors. Comments by some local visitors included that the Mile was not so golden anymore as it had gone downhill. They complained that it was not wellmaintained and that it was always crowded. This group of reviewers felt that the Mile had a lot of potential to be better. A few international visitors (2) seemed to think that the place was average, stating that it was just like other places of its nature.

Of the sample of 287 , only $12(4 \%)$ seemed to think that the appeal of the Golden Mile was poor, deserving only 2-stars. Of these reviewers only three were international from United Kingdom, Denmark and United States of America, with the remaining nine being local visitors. They seemed to think

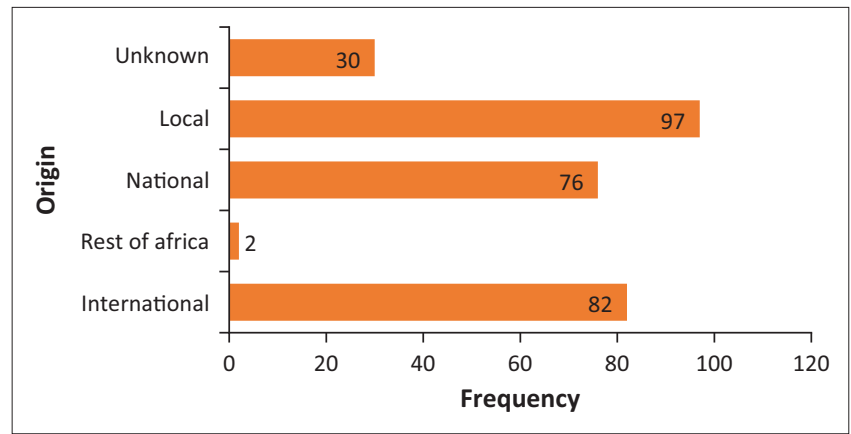

FIGURE 3: Places of origin of reviewers. 


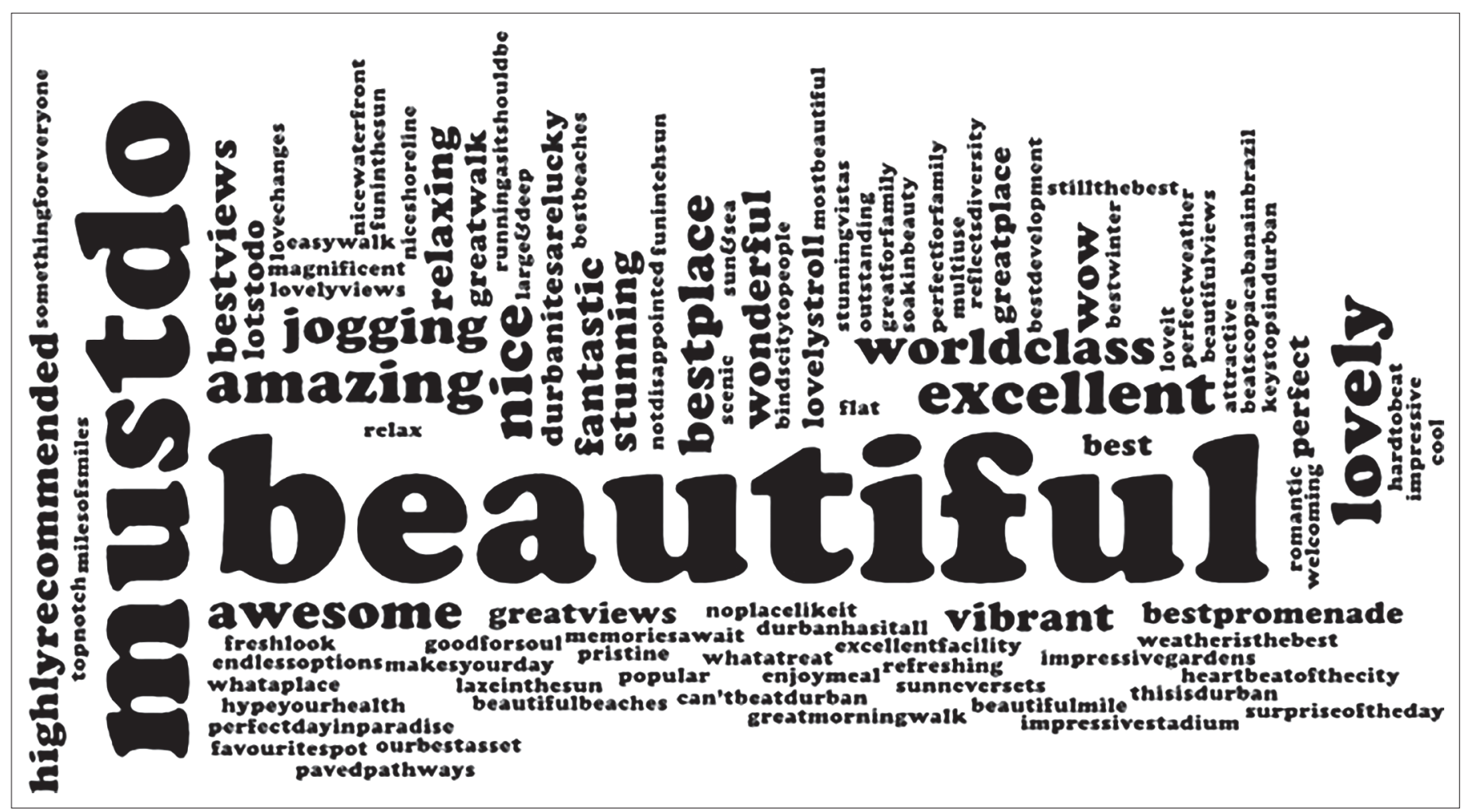

FIGURE 4: Data compilation on reviews of appeal of the Golden Mile.

that the Mile was tatty and sad with a rundown promenade and hotels that were far from shiny and glamourous. Only 5 $(1.7 \%)$ reviewers gave the Mile 1-star describing it as terrible. Of these, three were locals and two were internationals from the United States of America and Australia. The biggest criticisms were around neglect, the place having fallen from grace, it being third world and disappointing, with too many beggars loitering around.

\section{Reviews on experience}

Medway (2015), Medway et al. (2016), Russ et al. (2015) and Zhao (2018) argued that sensory and other non-visual inputs enhance the intensity of connection to the place as expressed in some of the words online reviewers used to express their experience such as fun, relaxing, enjoyable, lovely, leisurely, lots of fresh air, warm, breezy with great atmosphere. Some reviewers loved the upgrades done to the Mile, which should be encouraging and prompt further development of the place.

Words used by some reviewers to describe their experience of the place such as wind in my hair, sun kissed, surfers' paradise, wide open spaces, sea breeze graces your face, smell of the sea, place to reflect, romantic, one of a kind experience, fond memories, yearly cleansing, healing and culture shock, captured a level of affection, commitment, sentiment, emotions, personal intimacy and fantasies with the place (Trauer \& Ryan 2005; Zhao 2019). When reviewers used words such as exciting and electrifying features, beautiful sights, lots of entertainment, haven of activity, vibrant and cosmopolitan, colourful, suitable for wheelchair, iconic rickshaws and like I've visited the world, they illustrate thrown togetherness and interlacing of features in the same place as part of tourism placemaking and the place's ability to meet their diverse expectations.

\section{Reviews on safety}

Ferreira and Perks (2018), Haarhoff and Gany (2017), Kôvári and Zimányi (2011) and the United Nations World Tourism Organisation (1996) viewed safety and security as vital precondition to providing quality tourism and argued that the success and failure of a destination depend on it. A perception of safety is amongst the attributes of an attractive place (Kasim \& Dzakiria 2007). By the same breath, Gittins (2019), Mudzanani (2017) and Smith (2019:1) argued that safety and security have become the major threat and barrier to tourism in South Africa as the country's brand is seen as 'invisible at best and smelly at worst'. Perry and Potgieter (2013) argued that South Africa has created an image of being crime-ridden because of the media reporting, and Gittins (2019) and Smith (2019) attributed the 2.1\% decline in arrivals to safety and security concerns. The report pointed out that the biggest decline was in arrivals from Europe and Australia.

Figure 5 shows that whilst some reviewers did not comment on safety issues, those who did fell into two distinct categories of safe and unsafe. The cause and effect diagram (used by Hekmatpanah 2011; Kareem \& Jawwad 2020; Sakthiganesh \& Suchithra 2017) to present and analyse qualitative data in management and enginnering, respectively) was used to present online safety perceptions aligning them to the causes. The most frequent reviews were that visitors felt safe $27 \%$ (78) because of heavy police visibility (using vehicles, mounted on bicycles and walking), felt secure because of 


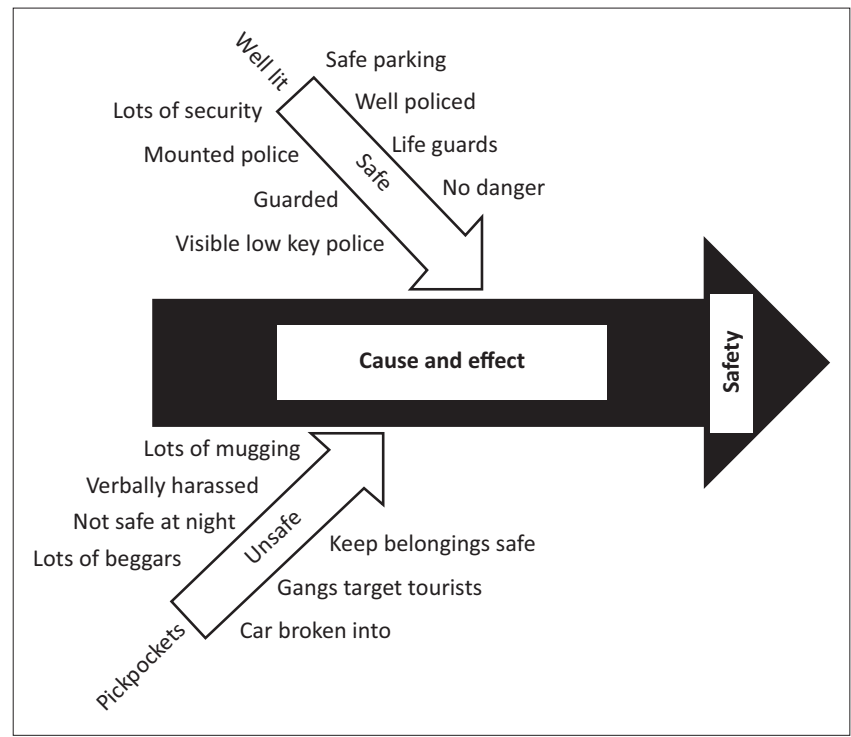

FIGURE 5: Data compilation on reviews on safety.

many life guards and lots of security. Some reviewers, 6\% (18) rating the Mile between 3-star and 1-star gave beggars, drunkenness, pickpocketing, mugging, harassment and rife criminality as reasons for feeling unsafe, especially at night and when you are alone. Safety and security reviews included comments such as: gangs target tourists like vultures, visitors being verbally harassed and the place not being recommended at night (United Kingdom 2017), lots of mugging, advice not to carry valuables (Johannesburg 2014) a car being broken into (Houtbay 2014) influence tourists when choosing their destination, especially because the residents and their behaviour are seen as part of the image, appeal and experience elements (Sinnoor \& Agadi 2015).

\section{Discussion}

Over and above pursuing special interests whilst at a destination (Trauer \& Ryan 2005), visitors also play an important role of providing feedback on the experience and feel of a place as was the case with the Mile. This article looked into the online visitor reviews of the Mile through the lenses of the placemaking theory to highlight the elements that turn a space into a place (Baldacchino 2012; Friedman 2010; Gagnon et al. 2014) through an amalgam of features and amenities thrown together to widen usership. Visitors' reviews were understood against the backdrop of their expectations of what a destination should offer as expounded by literature. Online destination reviews have become instrumental in predicting the performance of destinations as they give travellers a glimpse at the experiences of others (Alrawadieh et al. 2018). They are abundant open sources of free expression that shift visitors' role of being passive information receivers to that of active players in information generation and dissemination about the quality of destinations (Kim et al. 2019). Voluntary online destination reviews are perceived to be more trustworthy than destination marketing websites (Kladou \& Mavragani 2015) because visitors have nothing to gain or lose by giving realistic reviews.
The reviews on appeal qualify the Mile as a major visitor attraction, which Ram et al. (2016) considered to have strongest pull powers as key destination resources for development and marketing. In their words, and those of the reviewers, the Mile is a flagship and an iconic resource that draws large numbers of visitors to the city. As illustrated by these reviews, tourists' experiences of a facility are multidimensional, dynamic, subjective and driven by cognitive schemas and expectations (Vitterso et al. 2000), which Buonincontri, Marasco and Ramkissoon (2017) described as cognitive, affective, attitudinal and conative. Tourists' consumption of a place include rhythms (what the city does and how), textures (appearances, feel, tones), sounds (music, language, waves), smells and tastes (Pinkster \& Boterman 2017), meaning that their reviews were through their own lenses and expectations as discussed in the literature review. Medway (2015), Medway et al. (2016), Russ et al. (2015) and Zhao (2018) argued that sensory and other non-visual inputs enhance the intensity of connection to the place as expressed in some of the words they used to express these connections fun, enjoyable, relaxing, warm and lot of fresh air.

When reviewers used word such as exciting and electrifying features, beautiful sights, lots of entertainment, haven of activity, vibrant and cosmopolitan, colourful, suitable for wheelchair, iconic rickshaws and like I've visited the world and others, they were illustrating thrown togetherness and interlacing of features in the same place as part of tourism placemaking. Safety and security are vital precondition to providing quality tourism and have become the major threat and barrier to tourism in South Africa leading to 2.1\% drop in inbound tourism from January to September 2020. Perception of safety is amongst the attributes of place attractiveness (Kasim \& Dzakiria 2007). Such comments by reviewers as: hold tight to your belongings, be careful of pickpockets, crime is the biggest problem, be careful of scammers, not safe for solo traveler, crime puts me off, theft and pick pocketing rife, gangs target tourists like vultures, car was broken into and if you want crime this is the place to visit, even though sparsely distributed, can have negative influence on prospective visitors. The notion of South Africa being a crime hot spot was supported by Perry and Potgieter (2013) who stated that it creates negative perception of the place to inbound tourists.

It is important for eThekwini Municipality to read and factor users suggestions into future developments to improve the position of the Mile in the minds of visitors. As Baldacchino (2012), Parsaee et al. (2015) and Tallon (2018) pointed out, a place is a template that never reaches finality, but allows for making, unmaking and remaking as per users requests to preserve its uniqueness and avoid obsolescence (Wong \& Kaur Kler 1977). Understandably then, the structure of the Mile is not a 'fixed and eternal condition' (Parsaee et al. 2015:372) as discussed in the introduction, implying that visitors, whether local or international, as stakeholders to the Mile can use their reviews as their voices to feed forward to future development plans. 


\section{Conclusion}

The findings revealed adherence of the ideals of placemaking and alignment with visitors' expectations in terms of features and amenities already thrown together. The Mile offered a variety of physical, cultural and architectural elements, which are important attributes for destinations. The Mile as a place engaged with the visitors at different levels according to their dispositions as the reviews revealed. It provided room for unmaking and remaking as expected of destinations, even though the extent to which the reviews and input of users were taken into account still remained unclear. Visitors seemed to take online reviews seriously judging by the effort they put since the inception on the website in 2010. The reviews they gave were realistic including negative comments where required. The municipality needs to feedforward to the crucial visitors' concerns about criminality, skilling vendors not to harass visitors, dilapidated buildings, overcrowding especially during holiday seasons and variety in the curio stores. There are training, control and improvement implications for both the municipality and investors and concerted efforts to make use for solicited online reviews. This article has coordinated the online reviews of the visitors to the Mile, which should make it easier for the planners and tourism developers to read and factor into future developments. The article illustrated the significance of destination online reviews in tourism planning and development. Whilst the study focused on the Mile of Durban, lessons can be learnt by other tourism destinations to analyse their visitors' online reviews and use the results to aid continuous improvement.

The Mile is too busy a place to have accumulated only 891 reviews over a 10 year period. Mechanisms need to be put in place to encourage users to share their views and experiences, which they might if they realise that they are taken seriously and put to use. This study did not exhaust all the reviews available on the website. Further studies could look into crowd control during holiday seasons, it would be interesting to see how 2020-2021 the coronavirus disease 2019 (COVID-19) pandemic would impact the reviews and the issue of sustainability of proposed developments on the Mile amid the widespread lockdown.

\section{Acknowledgements Competing interests}

The author declares that she has no financial or personal relationships that may have inappropriately influenced her in writing this article.

\section{Author's contributions}

D.C.H. is the sole author for this article.

\section{Ethical considerations}

This article followed all ethical standards for research without direct contact with human or animal subjects.

\section{Funding information}

This research received no specific grant from any funding agency in the public, commercial or not-for-profit sectors.

\section{Data availability}

Data sharing is not applicable to this article as no new data were created or analysed in this study.

\section{Disclaimer}

The views and opinions expressed in this article are those of the author and do not necessarily reflect the official policy or position of any affiliated agency of the author.

\section{References}

Abel, S. \& Le Roux, P., 2017, 'Tourism an engine of wealth creation in Zimbabwe', International Journal of Economics and Financial Issues 7(2), 129-137.

Abou-Shouk, M.A., Zoair, N., El-Barbary, M.N. \& Hewedi, M.M., 2017, 'Sense of place with tourist satisfaction and intentional revisit: Evidence from Egypt', International Journal of Tourism Research 20(2), 172-181. https://doi. org/10.1002/jtr.2170

Alim, A., Ray, R. \& Hossain, E., 2018, Visitors' perception towards tour destinations: A study on Padma Garden, viewed 12 July 2020, from https://www.researchgate. net/-publication/324910222Visitors\%27PerceptiontowardsTourDestinationsAStu dyonPadmaGarden.

Alrawadieh, Z., Dincer, M.Z., Dincer, F.I. \& Mammadova, P., 2018, 'Understanding destination image from the perspective of Western travel bloggers: The case of Istanbul', International Journal of Culture, Tourism and Hospitality Research 12(1), 1-14. https://doi.org/10.1108/IJCTHR-12-2017-0124

Atinafu, B. \& Muuz, H., 2017, 'An investigation of the potential attibutes for tourist destination in six selected heritage sites of South Gondar, and the challenges in availing these heritage sites for tourists', Journal of Tourism and Hospitality 6(3), 1-10. https://doi.org/10.4172/2167-0269.1000289

Baldacchino, G., 2012, 'The Lure of the island: A spatial analysis of power relations', Journal of Marine and Island Cultures 1(2), 55-62. https://doi.org/10.1016/j. imic.2012.11.003

Barendse, J., Roux, D., Erfmann, W., Baard, J., Kraaij, T. \& Nieuwoudt, C., 2016, 'Viewshed and sense of place as conservation features: A case study and research agenda for South Africa's national parks', Koedoe - African Protected Area Conservation and Science 58(1), 1-16. https://doi.org/10.4102/koedoe. v58i1.1357

Barrera-Fernández, D. \& Hernández-Escampa, M., 2017, 'From cultural to creative tourism: Urban and social perspectives from Oaxaca, México', Revista de Turismo Contemporâneo-RTC, Natal 5(Special issue), 1-20

Blaschke, T., Merschdorf, H., Cabrera-Barona, P., Gao, S., Papadakis, E \& Kovacs-Györi, A., 2018, 'Place versus space: From points, lines and polygons in GIS to placebased representations reflecting language and culture', International Journal of Geo-Information 7(452), 1-26. https://doi.org/10.3390/ijgi7110452

Breek, P., Hermes, J., Eshuis, J. \& Mommaas, H., 2018, 'The role of social media incollective processes of place making: A study of two neighbourhood blogs in Amsterdam', City and Community 17(3), 906-924. https://doi.org/10.1111/ cico.12312

Bruno, S., Yang, C., Tian, W., Xie, Z. \& Shao, Y., 2019, 'Exploring the characteristics of tourism industry by analysing consumer review contents from social media: A case study of Bamako, Mali', Geo-Spatial Information Science 22(3), 214-222. case study of Bamako, Mali', Geo-Spatial Inform
https://doi.org/10.1080/10095020.2019.1649848

Brynskov, M., Carvajal Bermúdez, J.C., Fernández, M., Korsgaard, H., Mulder, I, Piskorek, K. et al., 2014, Urban interaction design: Towards city making, Sage, London.

Buonincontri, P., Marasco, A. \& Ramkissoon, H., 2017, 'Visitors' experience, place attachment and sustainable behaviour at cultural heritage sites: A conceptual framework', Sustainability 9(7), 1-19. https://doi.org/10.3390/su9071112

Calderwood, L.U. \& Soshkin, M., 2019, The travel and tourism competitiveness report 2019: Travel and tourism at a tipping point, World Economic Forum, Geneva.

Cerutti, S. \& Piva, E., 2016, 'The role of tourists' feedback in the enhancement of religious tourism destinations', International Journal of Religious Tourism and Pilgrimage 4(3), 6-16.

Chatzidakis, A., McEachern, M.G. \& Warnaby, G., 2018, 'Consumption in and of space and place: Introduction to the special issue', Marketing Theory 18(2), 149-153. https://doi.org/10.1177/1470593117732452

Cheer, J.M. \& Lew, A.A. (eds.), 2018, Tourism resilience and sustainability: Adapting to social, political and economic change, Routledge, London.

Cloete, M. \& Yusuf, S., 2018, 'Conceptual commentary of public spaces in Durban, South Africa', African Journal Online 73(3), 35-46. https://doi.org/10.18820/24150495/trp73.3 
Dameria, C., Akbar, R. \& Indradjati, P.N., 2018, 'Whose sense of place? Re-thinking place concept and urban heritage conservation in social media era', Earth and place concept and urban heritage conservation in social media era', Earth and
Environmental Science 158, 1-12. https://doi.org/10.1088/1755-1315/158/ Environmenta

De Brito, M. \& Richards, G., 2017, 'Events and placemaking', Special Issue of the International Journal of Event and Festival Management 8(1), 1-15. https://doi. org/10.1108/IJEFM-09-2016-0063

Dediu, L., 2016, 'Users' reviews on tourism sites: Their influence on the potential tourists', Cactus Tourism Journal 13(1), 41-55.

De Villiers, J., 2019, 'Take a look: Durban's new R380 million beachfront promenade upgrade is nearly done', Business Insider, October 24, 2019, viewed 17 May 2020, from http://www.businessinsider.co.za

D’Orey, F., Cardoso, A. \& Abreu, R., 2019, 'Tourist sense of place, an assessment of the sense of place in tourism studies: The case of Portugal', Academy of Strategic Management Journal 18(1), 1-14.

Durban Point Waterfront, 2020, The Master Plan, viewed 04 May 2020, from https:// www.durbanpoint.co.za/master-plan

Dwyer, L., Mellor, R., Livaic, Z., Edwards, D. \& Kim, C., 2004, 'Attributes of destination competitiveness: A factor analysis', Tourism Analysis 9(1-2), 91-101. https://doi. org/10.3727/1083542041437558

Ebejer, J., 2014, 'Meaning of place and the tourist experience', in conference: Tourism research symposium: Tourism, Malta and the Mediterranean, Floriana, Malta, July 16-17, 2014, viewed 12 July 2020, from https://www.um.edu.mt/library/oar// handle/123456789/16638

Elrahman, A.S.A. \& Asaad, M., 2020, 'Urban design and urban planning: A critical analysis to the theoretical relationship gap', Ain Shams Engineering Journal 12(1) 1163-1173. https://doi.org/10.1016/j.asej.2020.04.020

Ferreira, D. \& Perks, S., 2018, 'Satisfiers and dissatisfies in the destination selection process: A cultural demographic approach', African Journal of Hospitality, Tourism and Leisure 7(5), 1-15.

Fleischer, M., Fuhrmann, M., Haferburg, C. \& Krüger, F., 2013, “"Festivalisation” of Urban Governance in South African cities: Framing the urban social sustainability of mega-event driven development from below', Sustainability 5(12), 5225-5248. https://doi.org/10.3390/su5125225

Fox, L., 2019, 'Booking.com talks up importance of reviews in travel decisions, especially for rentals', Phocus Wire, viewed 18 June 2020, from https://www.phocuswire.com

Friedman, J., 2010, 'Place and placemaking in cities: A global perspective', Journal of Planning, Theory and Practice 11(2), 149-165. https://doi.org/10.1080/ Planning, Theory and
14649351003759573

Gagnon, M., Jacob, J.D. \& McCabe, J., 2014, 'Locating the qualitative interview: Reflecting on space and place in nursing research', Journal of Research in Nursing 20(3), 1-13. https://doi.org/10.1177/1744987114536571

Geographic Information System (GIS), 2021, viewed 12 July 2020, from https://www. google.com/maps/search/GIS+2021+map+of+kwazulu+natal/@ $28.9262832,28.6383794,7 z /$ data $=! 3 m 1 ! 4 b 1$

Ghoomi, H.A., Yazdanfar, S., Hosseini, S. \& Maleki, S.N., 2015, 'Comparing the components of sense of place in the traditional and modern residential neighbourhoods, Asian conference on environment-behaviour studies, AcEBs2015, February 20-22, 2015, Tehran, Iran', Procedia - Social and Behavioral Sciences 201, 275-285. https://doi.org/10.1016/j.sbspro.2015.08.176

Gittins, M., 2019, 'Tourism safety strategy to combat decline in visitors', Southern \& East African Tourism Update, viewed 27 May 2020, from https://www.tourismupdate. co.za

Haarhoff, R. \& Gany, K.B., 2017, 'Attributes that influence resort attractiveness: A case study of selected Kimberley resorts', African Journal of Hospitality, Tourism and Leisure 6(3), 1-21.

Harvie, A., 2020, Placemaking, viewed 28 May 2020, from https://www.designingbuildings. co.uk/wiki/Placemaking

Hekmatpanah, M., 2011, 'The application of cause and effect diagram in the oil industry in Iran: The case of four litre canning process of Sepahan oil company', African Journal of Business Management 5(26), 10900-10907. https://doi. African Journal of Business
org/10.5897/AJBM11.1517

Hlee, S., Lee, H. \& Koo, C., 2018, 'Hospitality and tourism online review research: A systematic analysis and heuristic-systematic model', Sustainability 10(1141), 1-27. https://doi.org/10.3390/su10041141

Hossain, K. \& Islam, S., 2019, 'An analysis of destination attributes to enhance tourism competitiveness in Bangladesh', African Journal of Hospitality, Tourism and Leisure 8(2), 1-17.

Jagganath, T., 2018, Theories on public spaces: A case study of Trafalgar Square, viewed 14 July 2020, from https://medium.com/@thejas009/theories-on-public spaces-a-case-study-of-trafalgar-square-de868550ad71

Kareem, A. \& Jawwad, A.K.M.A., 2020, 'A novel qualitative-quantitative cause-andeffect tool for analysis, presentation and decision-support', Industrial Engineering and Management Systems 19(2), 412-425. https://doi.org/10.7232/ iems.2020.19.2.412

Kasim, A. \& Dzakiria, H., 2007, 'Luring the tourists: A positioning exercise', Asia Pacific Journal of Tourism Research 6(2), 40-52. https://doi.org/10.1080/ 10941660108722098

Kim, H., Joun, H.J., Choe, Y. \& Schroeder, A., 2019, 'How can a destination better manage its offering to visitors? Observing visitor experiences via online reviews', Sustainability 11(17), 4660. https://doi.org/10.3390/su11174660

Kitingan, A., 2019, 'The importance of online reviews in marketing', Tourism tattlers, news, views and reviews for travel in, to and out of Africa, viewed 24 June 2020, from https://www.tourismtattler.com
Kladou, S. \& Mavragani, E., 2015, 'Assessing destination image: An online marketing approach and the case of tripadvisor', Journal of Destination Marketing \& Management 4(3), 187-193. https://doi.org/10.1016/j.jdmm.2015.04.003

Kolas, A., 2004, 'Tourism and the making of place in Shangri-La', Tourism Geographies 6(3), 262-278. https://doi.org/10.1080/1461668042000249610

Kôvári, I. \& Zimányi, K., 2011, 'Safety and security in the age of global tourism: The changing role and conception of safety and security in tourism'. Applied Studies in Agribusiness and Commerce 5(3-4), 59-61. https://doi.org/10.19041/ APSTRACT/2011/3-4/10

Lew, A.A., 2017a, 'Tourism planning and place making: Place-making or placemaking?', Tourism Geographies 19(3), 1-21. https://doi.org/10.1080/14616688.2017.1282 007

Lew, A.A., 2017b, 'Tourism, place making and mobility: An interview with Alan A. Lew', Europe Now Journal, viewed 26 May 2020, from https://www.europenowjournal. org/2017/09/05/tourism-place-making-and-mobility-an-interview-with-alan-alew

Martins, M., 2015, 'The tourist imagery, the destination image and the brand image', Journal of Tourism and Hospitality Management 3(2), 1-14. https://doi. org/10.15640/jthm.v3n2a1

Massey, D., 2005, For space, Sage, London.

Massey, D., Allen, J. \& Sarre, P., 1999, Human geography today, Polity Press, Cambridge.

Matema, M., 2018, 'Durban tourism sector, South Africa is ready for the 2022 Commonwealth Games', Nomad Africa Magazine, 18 April, 2018, viewed n.d., from https://www.nomadafricamag.com

Medway, D., 2015, Place branding and the other senses, in rethinking place branding: Comprehensive brand development for cities and regions, Springer, Berlin.

Medway, D., Parker, C., Quin, S. \& Roberts, G., 2016, 'Changing places: Placing change', Journal of Place Management and Development 9(1), 191-209. https://doi. org/10.1108/JPMD-02-2016-0007

Mottier, Z. \& Ryan, T., 2019, 'An examination of the role of placemaking in tourism on the entrepreneurial ecosystem', in AIRTH conference innovation in motion, University of Innsbruck, September 12-14, 2019.

Mudzanani, T.E., 2017, 'Examining newspaper articles on tourism and crime in South Africa', African Journal of Hospitality, Tourism and Leisure 6(2), 1-8.

Naidoo, S., 2019, Durban beachfront promenade gets $R 380$ million extension, viewed 24 June 2020, from http://www.moneyweb.co.za

Neto, A.Q., Dimmock, K., Lohmann, G. \& Scott, N., 2019, 'Destination competitiveness: How does travel experience influence choice?', Current Issues in Tourism 23(13), 1673-1687. https://doi.org/10.1080/13683500.2019.1641070

Northrop, A. \& Neumann, B., 2016, Placemaking in tourism - How to attract new visitors and talent to your region, Michigan State University, viewed 03 June 2020, from https://www.canr.msu.edu

Open Streets, 2017, Successful public spaces in South Africa, viewed 17 June 2020 from https://openstreets.org.za/news/successful-public-spaces-south-africa

Parsaee, M., Parva, M. \& Karimi, B., 2015, 'Space and place concepts analysis based on semiology approach in residential architecture: The case study of traditional city of Bushehr, Iran', Housing and Building National Research Center Journal 11(3), 368-383. https://doi.org/10.1016/j.hbrcj.2014.07.001

Perry, E.C. \& Potgieter, C., 2013, 'Crime and tourism in South Africa', Journal of Human Ecology 43(1), 101-111. https://doi.org/10.1080/09709274.2013.11906616

Pinkster, F.M. \& Boterman, W.R., 2017, 'When the spell is broken: Gentrification, urban tourism and privileged discontent in the Amsterdam Canal district', Cultural Geographies 24(3), 457-472. https://doi.org/10.1177/1474474017706176

Raissi, N. \& Eshghi, S.H., 2012, The ratio of space and place due to architecture Relying on the thoughts of Martin Heidegger and Christine Norberg-Schulz, viewed 28 May 2020, from http://www.magiran.com/npview.asp?ID=2478696

Ram, Y., Bjork, P. \& Weidenfeld, A., 2016, 'Authenticity and place attachment of major visitor attractions', Tourism Management 52, 110-122. https://doi.org/10.1016/j. visitor attractions', Tourism

Ramkinssoon, H., Weiler, B. \& Smith, G., 2012, 'Place attachment and proenvironmental behaviour in national parks: The development of a conceptual framework', Journal of Sustainable Tourism 20(2), 257-276. https://doi.org/10.10 80/09669582.2011.602194

Raymond, C.M., Gottwald, S., Kouppa, J. \& Kytta, M., 2016, 'Integrating multiple elements of environmental justice into urban blue space planning using public participation', Landscape and Urban Planning 153(C), 198-208. https://doi. participation, Landscape and Urban Plan
org/10.1016/j.landurbplan.2016.05.005

Relph, E., 1993, Modernity and the reclamation of place: Dwelling, seeing, and designing: Toward a phenomenological ecology, Sunny Press, Albany NY.

Rocamora, J.A.L., 2019, 'Sustainable tourism: Luring tourists, protecting nature's gems', Republic of Philippines, Philippine News Agency, viewed 02 June 2020, from https://www.pna.gov.ph

Rodríguez-Díaz, B. \& Pulido-Fernández, J.I., 2019, 'Sustainability as a key factor in tourism competitiveness: A global analysis', Sustainability 12(51), 1-19. https:// doi.org/10.3390/su12010051

Roult, R., Adjizian, J. \& Auger, D., 2016, 'Sense of place in tourism and leisure: The case of touring skiers in Quebec', Journal of Tourism, Culture and Territorial Development 7(13), 79-94.

Russ, A., Peters, S.J.E., Krasny, M. \& Stedman, R.C., 2015, ‘Development of ecological place meaning in New York City', Journal of Environmental Education 46(2), 73-93. https://doi.org/10.1080/00958964.2014.999743 
Sakthiganesh, R. \& Suchithra, S., 2017, 'A qualitative approach for analyzing causes and effects of construction risks', International Research Journal of Engineering and Technology $4(1), 885-887$.

Schuckert, M., Liu, X. \& Law, R., 2015, 'Hospitality and tourism online reviews: Recent trends and future directions', Journal of Travel \& Tourism Marketing 32(5), 608-621. https://doi.org/10.1080/10548408.2014.933154

Sinnoor, G.B. \& Agadi, R., 2015, 'Residents' perceptions of a tourist destination: An empirical study of Hyderabad Karnataka region', African Journal of Hospitality, Tourism and Leisure 4(2), 1-21.

Smith, C., 2019, 'Minister concerned as safety, security issues take toll on tourism stats', Fin24, November 20, 2019, viewed 14 June 2020, from http://m.fin24. com

Sofield, T., Guia, J. \& Specht, J., 2017, 'Organic "folkloric" community driven placemaking and tourism', Tourism Management 61, 1-22. https://doi.org/10.1016/j. tourman.2017.01.002

Staiff, R. \& Bushell, R., 2017, 'The "old" and the "new": Events and placemaking in Luang Prabang, Laos', International Journal of Event and Festival Management 8(1), 55-65. https://doi.org/10.1108/IJEFM-05-2016-0036

Tallon, C., 2018, What is placemaking? Place engage: Better placemaking together viewed 15 May 2020, from http://www.placeengage.com

Toolis, E.E., 2017, 'Theorizing critical placemaking as a tool for reclaiming public space', American Journal of Community Psychology 59(1-2), 184-199. https://doi. org/10.1002/ajcp.12118

Toral, S.L., Martínez-Torres, M.R. \& Gonzalez-Rodriguez, M.R., 2017, 'Identification of the unique attributes of tourist destinations from online reviews', Journal of Travel Research 57(1), 1-12. https://doi.org/10.1177/0047287517724918

Trancik, R., 1986, Finding lost space, Van Nostrand, New York, NY.

Trauer, B. \& Ryan, C., 2005, 'Destination image, romance and place experience - An application of intimacy theory in tourism', Tourism Management 26(4), 481-491. https://doi.org/10.1016/j.tourman.2004.02.014

Tsai, S.P., 2012, 'Place attachment and tourism marketing: Investigating international tourists in Singapore', International Journal of Tourism Research 14(2), 139-152. https://doi.org/10.1002/jtr.842
Tuan, Y.F., 1977, Space and Place: The Perspective of Experience, University of Minnesota Press, Minnesota.

United Nations World Tourism Organisation, 1996, Tourism safety and security: Practical measures for destinations, UNWTO Secretariat, Madrid.

Vinyals-Mirabent, S., 2019, 'European urban destinations' attractors at the frontier between competitiveness and a unique destination image', Journal of Destination Marketing and Management 12(1), 37-45. https://doi.org/10.1016/j.jdmm.2019.02.006

Vitterso, J., Vorkinn, M., Vistad, O.I. \& Vaagland, J., 2000, 'Tourist experiences and attractions', Annals of Tourism Research 27(2), 432-450. https://doi.org/10.1016/ S0160-7383(99)00087-0

Wagenaar, H., 2011, Meaning in action: Interpretation and dialogue in policy analysis, M.E. Sharpe, London.

Wesener, A., Fox-Kämper, R., Sondermann, M. \& Münderlein, D., 2020, 'Placemaking in action: Factors that support or obstruct the development of urban community gardens', Sustainability 12(2), 657. https://doi.org/10.3390/su12020657

Williams, D.R., 2014, 'Making sense of place: Reflections on pluralism and positionality in place research', Landscape and Urban Planning 131(1), 74-82. https://doi. org/10.1016/j.landurbplan.2014.08.002

Wong, P.P.L. \& Kler, B.K., 1977, 'Understanding Sense of Place in Tourism Development: The Case of Tunku Abdul Rahman Park, Sabah', BEST Education Network Think Tank XIII: Engaging Communities in Sustainable Tourism Development, University of Malaysia, pp. 311-312, viewed 25 September 2020, from http://www. besteducationnetwork.org

Ye, H. \& Tussyadiah, I.P., 2011, 'Destination visual image and expectation of experiences', Journal of Travel and Tourism Marketing 28(2), 129-144. https:// doi.org/10.1080/10548408.2011.545743

Yuksel, A., Yuksel, F. \& Bilim, Y., 2010, 'Destination attachment: Effects on customer satisfaction and cognitive, affective and conative loyalty', Tourism Management 31(2), 274-284. https://doi.org/10.1016/j.tourman.2009.03.007

Zhao, L., 2019, 'The sense of place for tourists: Place-making under the perspectives of symbolic interaction and phenomenology', Advances in Economics, Business and Management Research 85(1), 598-605. https://doi.org/10.2991/icoeme-19.2019.112

Zhou, Z., 2018, 'A survey of visitor satisfaction at Victoria Falls Rainforest', African Journal of Hospitality, Tourism and Leisure 7(1), 1-21. 